\title{
Peningkatan Kemampuan Guru dalam Menyusun RPP Terintegrasi Adiwiyata Berbasis Isu-Isu Kritis Lokal pada Calon Sekolah Adiwiyata di Tanjungpinang
}

\author{
Nur Eka Kusuma Hindrasti ${ }^{1 *}$, Azza Nuzullah Putri² ${ }^{2}$ Erda Muhartati ${ }^{3}$ \\ 1,2,3 Prodi Pendidikan Biologi FKIP UMRAH
}

\section{A R T I C L E I N F O}

Article history:

Received 20 May 2019

Received in revised form

10 June2019

Accepted 30 Julyl 2019

Available online 27 August 2019

\section{Kata Kunci:}

RPP adiwiyata, isu kritis

local

Keywords:

cultivation of toga plants

Learning design of

adiwiyata, local critical

issues

\section{A B S T R A K}

Pembelajaran menjadi aspek yang sangat menentukan dalam penilaian adiwiyata. Namun, merancang pembelajaran terintegrasi adiwiyata masih menjadi kendala bagi guru. Sehingga sebagian besar sekolah tidak dapat mencapai batas minimum untuk lolos menjadi sekolah adiwiyata baik tingkat kota, provinsi, maupun nasional. Selain lemah dalam merancang pembelajaran berupa RPP, guru juga kurang mampu mengangkat isu lokal. Sedangkan sekolah adiwiyata di Tanjungpinang baru mencapai tidak lebih dari 20\%. Peningkatan kemampuan guru Tanjungpinang dalam menyusun RPP terintegrasi adiwiyata yang berbasis kearifan lokal mutlak diperlukan agar sekolah adiwiyata di Tanjungpinang semakin meningkat. Kegiatan pengabdian kepada masyarakat (PKM) ini dilakukan bagi guru-guru calon sekolah adiwiyata tingkat kota, sekolah adiwiyata tingkat kota, dan sekolah adiwiyata tingkat provinsi di Tanjungpinang. Kegiatan dilakukan dalam bentuk pelatihan dan pendampingan penyusunan RPP. Tujuannya adalah untuk meningkatkan kemampuan menyusun RPP terintegrasi adiwiyata berbasis isu-isu kritis lokal bagi guru-guru di Kota Tanjungpinang. Pelaksanaan kegiatan dalam bentuk pelatihan tatap muka dan daring mulai tanggal 10-17 Oktober 2018. Evaluasi dilakukan dengan teknik observasi, unjuk kinerja, serta pretes dan postes. Observasi dilakukan untuk mengetahui keterlaksanaan kegiatan. Hasil observasi menunjukkan bahwa kegiatan PKM bagi guru-guru terlaksana dengan baik. Guru-guru antusias dan terlibat aktif dalam mengikuti kegiatan. Hasil unjuk kinerja berupa penyusunan RPP Adiwiyata, menunjukkan bahwa $83 \%$ guru sudah mampu meningkatkan kemampuannya dalam menyusun RPP. Berdasarkan hasil analisis pretes-postes menunjukkan bahwa terdapat peningkatan pengetahuan guru dalam menyusun RPP Adiwiyata. RPP yang digunakan oleh sekolah adiwiyata sebenarnya sama dengan RPP sesuai regulasi kurikulum Kemendiknas, karena regulasi kurikulum sudah memuat pelestarian lingkungan. Dengan demikian tidak ada istilah khusus untuk RPP dan kurikulum sekolah yang melaksanakan adiwiyata.

\section{A B S T R A C T}

Learning becomes a very decisive aspect in the assessment of adiwiyata. However, designing integrated learning adiwiyata is still an obstacle for teachers. So that most schools cannot reach the minimum limit to qualify to become adiwiyata schools both at the city, provincial and national levels. Besides being weak in designing learning in the form of RPP, teachers are also less able to raise local issues. Whereas the adiwiyata school in Tanjungpinang only reached no more than $20 \%$. Increasing the capacity of Tanjungpinang teachers in developing adiwiyata integrated RPP based on local wisdom is absolutely necessary so that adiwiyata schools in Tanjungpinang will increase. Community service activities (PKM) have been carried out for teachers of candidates for city-level adiwiyata schools, city-level adiwiyata schools, and provincial-level adiwiyata schools in Tanjungpinang. The

\footnotetext{
Corresponding author.

E-mail addresses: nurekakh20117@umrah.ac.id (Nur Eka Kusuma Hindrasti)
} 
activity was carried out in the form of training and mentoring in the preparation of the RPP. This activity aims to improve the ability to develop adiwiyata integrated RPP based on local critical issues for teachers in Tanjungpinang City. Implementation of activities is face-to-face workshop and online activities starting from 10-17 October 2018. Evaluation is done by observation techniques, performance shows, and pretest and posttest. Observations were made to determine the implementation of the activity. The results of the observation indicate that PKM activities for teachers are well implemented. Enthusiastic teachers and actively involved in participating in the activities. The results of the performance show in the form of the Adiwiyata RPP, showed that $83 \%$ of teachers had been able to improve their abilities in preparing lesson plans. Based on the results of the pretestposttest analysis showed that there was an increase in teacher knowledge in compiling the Adiwiyata RPP. The RPP used by adiwiyata schools is actually the same as RPP according to the Ministry of National Education curriculum regulations, because curriculum regulations already contain environmental preservation. Thus there is no specific term for RPP and school curriculum that implements adiwiyata.

Copyright (C) Universitas Pendidikan Ganesha. All rights reserved.

\section{Pendahuluan}

Undang-undang Nomor 32 Tahun 2009 pasal 65 ayat (2) tentang Perlindungan dan Pengelolaan Lingkungan Hidup mengamanatkan bahwa setiap orang berhak mendapatkan pendidikan lingkungan hidup, termasuk siswa sebagai generasi penerus bangsa. Pemerintah telah mengupayakan merealisasikan amanat Undang-undang tersebut dengan membentuk program sekolah adiwiyata. Sejalan dengan pendapat Desfandi (2015), yang menyatakan bahwa mengembangkan masyarakat berkarakter peduli lingkungan dimungkinkan dapat efektif melalui pendidikan lingkungan di sekolah melalui program adiwiyata.

Sekolah Adiwiyata adalah sekolah yang peduli dan berbudaya lingkungan. Sedangkan program adiwiyata adalah program untuk mewujudkan sekolah yang peduli dan berbudaya lingkungan. Program adiwiyata dilaksanakan berdasarkan prinsip edukatif, partisipatif, dan berkelanjutan (Permen LH Nomor 05 Tahun 2013 tentang Pedoman Pelaksanaan Program Adiwiyata). Prinsip edukatif merupakan prinsip yang utama dan pertama, menempatkan siswa sebagai agen yang harus dipastikan memiliki kepedulian dan budaya lingkungan. Prinsip ini dapat diwujudkan dalam pembelajaran-pembelajaran baik di dalam kelas maupun di luar kelas. Menurut Anwari (2014), 4 (empat) strategi untuk membangun karakter peduli lingkungan di sekolah adalah melalui proses belajar dan mengajar (pembelajaran), budaya sekolah, kegiatan ektrakurikuler, dan keterlibatan orang tua murid. Pembelajaran merupakan strategi utama dalam mengimplementasikan adiwiyata. Seharusnya apapun kegiatan sekolah baik yang dilaksanakan oleh guru, kepala sekolah, komite, masyarakat di lingkungan sekolah, dan tukang kebun dalam melaksanakan program adiwiyata, terintegrasi dengan pembelajaran, karena pembelajaran adalah bussiness core program adiwiyata. Artinya percuma jika sekolah sudah banyak melakukan kegiatan program adiwiyata jika siswa tidak dilibatkan, tidak diberi tahu, dan dipahamkan. Pelibatan kegiatan sekolah pada pembelajaran dapat dicontohkan sebagai berikut: tulisan guru pada surat kabar dapat dijadikan wacana pada mata pelajaran Bahasa Indonesia materi tanda baca.

Adanya program adiwiyata di sekolah dianggap dapat menumbuhkembangkan karakter peduli lingkungan. Hal tersebut diperkuat oleh penelitian Saragih (2012), bahwa ada pengaruh positif dari program adiwiyata terhadap ranah kognitif, afektif, dan psikomotorik dari lingkungan. pendidikan lingkungan hidup yang dilakukan di sekolah adiwiyata dinilai efektif dalam menumbuhkan kepedulian terhadap kelestarian sumberdaya alam dan lingkungan (Mulyana, (2009). Manurung (2011) juga menemukan hasil penelitian yang senada, yaitu program adiwiyata yang telah dilaksanakan oleh SDN Panggang 04 Jepara telah mampu menumbuhkembangkan karakter peduli lingkungn. Hal tersebut dapat dilihat melalui kegiatan spserti menanam dan merawat tanaman, memilah dan membuang sampah, menghemat pemakaian air, listrik, dan kertas.

Penilaian adiwiyata yang ditegaskan oleh Peraturan Menteri Lingkungan Hidup No.05 Tahun 2013, meliputi komponen: (1) kebijakan sekolah yang berwawasan lingkungan, (2) kurikulum sekolah berbasis lingkungan, (3) kegiatan sekolah berbasis partisipatif, dan (4) pengelolaan sarana dan prasarana pendukung sekolah yang ramah lingkungan. Pembelajaran merupakan pelaksanaan kurikulum yang mendukung komponen kedua. Indikator pembelajaran yang terintegrasi lingkungan (adiwiyata) adalah tenaga pendidik memiliki kompetensi dalam mengembangkan kegiatan pembelajaran lingkungan hidup 
dan peserta didik melakukan kegiatan pembelajaran tentang perlindungan dan pengelolaan lingkungan hidup. Peranan guru sebagai tenaga pendidik sangat penting dalam pembelajaran lingkungan hidup. Guru dituntut kreatif mengintegrasikan konsep pada mata pelajaran dengan prinsip pengelolaan dan perlindungan lingkungan hidup. Hasil UKG pada aspek kemampuan pedagogik atau pembelajaran belum optimal, yaitu mencapai 53,02 dari KKM yang ditargetkan pemerintah 55,00. Hal tersebut menjadi indikator bahwa guru masih kesulitan dan belum kreatif dalam merancang dan melaksanakan pembelajaran, apalagi pembelajaran yang diintegrasikan dengan adiwiyata. Pelatihan-pelatihan untuk guru masih sangat relevan untuk dilakukan. Sebagaimana Suratman dkk (2017) telah berupaya meningkatkan kreativitas guru melalui pelatihan model pembelajaran saintifik berbasis pantai dan laut.

Sekolah di Tanjungpinang tidak seluruhnya antusias dengan program adiwiyata, terbukti dari sekitar 125 sekolah yang ada, sekitar 20 sekolah yang baru meraih penghargaan sebagai sekolah adiwiyata. Berdasarkan data yang diperoleh dari DLH Kota Tanjungpinang, diketahui bahwa aspek kurikulum sekolah berbasis lingkungan menjadi aspek yang memberikan dukungan skor terkecil dibanding aspek yang lain. Sehingga sebagian besar sekolah tidak dapat mencapai batas minimum untuk lolos menjadi sekolah adiwiyata baik tingkat kota, provinsi, maupun nasional. Batas minimum untuk lolos menjadi sekolah adiwiyata tingkat kota adalah 56 atau $70 \%$ dari total nilai maksimal (80), tingkat provinsi 64 atau $80 \%$ dari total nilai maksimal, dan tingkat nasional 72 atau 90\% dari total nilai maksimal. Sedangkan untuk menjadi sekolah adiwiyata mandiri, sekolah adiwiyata tingkat nasional harus sudah membina minimal 10 sekolah yang telah mendapat penghargaan adiwiyata tingkat kabupaten/kota. Sekolah adiwiyata mandiri dapat diusulkan untuk ikut dalam seleksi penerimaan penghargaan tingkat Asean Eco School (AES).

Catatan dari penilai adiwiyata nasional untuk sekolah adiwiyata tingkat provinsi menunjukkan bahwa masih terdapat kekurangan dalam mengangkat isu global maupun lokal. Disebutkan bahwa RPP belum memuat isu lokal dengan mengangkat keanekaragaman daerah/kearifan lokal setempat dan isu global. Hal ini menunjukkan, selain lemah dalam merancang pembelajaran berupa RPP, guru juga kurang mampu mengangkat isu kritis lingkungan lokal, nasional, maupun global. Kepri dikenal dengan negeri gurindam dan kental dengan budaya melayu. Menurut Hindrasti (2017) kearifan lokal Kepri dapat dibedakan menjadi tiga yaitu: (a) Lingkungan fisik yang khas dari Kepri, contohnya air terjun, gunung, (b) Biodiversitas Kepri, seperti Gonggong, Pohon Keruing, (c) Kebudayaan Kepri, contohnya Tudung manto, upacara-upacara adat. Pengetahuan kearifan lokal Kepri tersebut sebagai bekal dalam menganalisis isu kritis lingkungan lokal. Dengan adanya pengetahuan yang cukup tentang isu-isu lingkungan yang ada dan akibat yang dapat timbul karena gangguan manusia merupakan tuntutan dalam pengelolaan lingkungan yang bijak (Zoer'aini, 2012).

Bertolak dari fenomena yang diuraikan di atas maka untuk mewujudkan semakin banyaknya sekolah adiwiyata di Kota Tanjungpinang, maka upaya meningkatkan kemampuan guru dalam menyusun RPP terintegrasi adiwiyata berbasis isu-isu kritis lokal Kepri sangat diperlukan. Oleh karena itu perlu diadakan kegiatan pengabdian kepada masyarakat bagi guru-guru Calon sekolah adiwiyata agar guruguru tersebut memiliki keterampilan dalam merancang pembelajaran berbasis adiwiyata yang memperhatikan kearifan lokal Kepri. Bekal keterampilan yang dimiliki oleh guru setelah mengikuti pelatihan diharapkan dapat diajarkan ke guru-guru lain di sekolahnya masing-masing. RPP yang dihasilkan diharapkan dapat digunakan dan disempurnakan secara berkelanjutan sehingga sekolah adiwiyata di Tanjungpinang semakin bertambah.

\section{Metode}

Metode yang diterapkan dalam pengabdian ini adalah mengungkap pemasalahan yang muncul di kalangan guru terkait persiapan menuju sekolah adiwiyata, dilanjutkan dengan pelatihan secara tatap muka, yang terakhir pendampingan penyusunan RPP. Tahapan pelaksanaan kegiatan pengabdian adalah: (a) melakukan kunjungan ke DLH Tanjungpinang untuk mendapatkan data calon sekolah adiwiyata dan menggali kebutuhan calon sekolah adiwiyata terkait pembelajaran yang terintegrasi adiwiyata; (b) mengirimkan undangan ke dinas pendidikan Kota Tanjungpinang; (d) peserta pelatihan diminta membawa RPP yang pernah dibuat terutama yang terintegrasi dengan adiwiyata; (e) pelatihan penyusunan RPP terintegrasi adiwiyata berbasis isu-isu kritis lokal Kepri yang diawali dengan penyampaian materi pertama tentang Adiwiyata, materi kedua tentang penyusunan RPP terintegrasi adiwiyata, kemudian pelatihan penyusunan RPP, dilanjutkan pendampingan penyusunan RPP di sekolah; (f) analisis peningkatan kemampuan guru dalam menyusun RPP sebelum dan sesudah pelatihan.

Evaluasi dilakukan untuk 1) mengetahui keterlaksanaan kegiatan dengan teknik observasi meggunakan instrumen lembar observasi, 2) mengetahui peningkatan kemampuan menyusun RPP Adiwiyata dengan membandingkan RPP sebelum dan mengikuti pelatihan menggunakan instrumen 
lembar penilaian dan instrumen unjuk kinerja, dan 3) mengetahui peningkatan pengetahuan dalam penyusunan RPP Adiwiyata dengan teknik tes menggunakan lembar pretes dan postes. 24 orang guru sebagai peserta pelatihan, mengisi pretes dan postes dan mengembalikannya ke panitia. Teknik unjuk kinerja digunakan untuk menilai kinerja guru dalam menyusun RPP Adiwiyata. Setelah mengikuti pelatihan hanya 20 orang yang menyusun RPP Adiwiyata dan menyerahkan ke panitia.

Data dari observasi keterlaksanaan kegiatan dianalisis secara deskriptif kualitatif dengan menjelaskan ketercapaian aspek-aspek keterlaksanaan kegiatan. Aspek-aspek tersebut adalah 1) terlaksananya kegiatan sesuai susunan dalam rundown acara, 2) kegiatan meliputi pembukaan, pemaparan materi, tanya jawab interaktif, dan penutupan, 3) terlaksana sesuai waktu yang direncanakan, 4) terdapat interaksi dua arah antara peserta dan pemateri, dan 5) terdapat tindak lanjut dari kegiatan pelatihan.

Data dari lembar penilaian RPP sebelum dan setelah pelatihan dianalisis secara deskriptif kualitatif dengan menjelaskan secara umum apakah RPP sebelum dan setelah pelatihan sudah memenuhi kriteria penyusunan RPP. Sedangkan data dari pretes dan postes dianalisis secara kuantitaif dengan melihat ratarata nilai pretes dan postes dari seluruh peserta.

\section{Hasil dan Pembahasan}

Wawancara kepada staff DLH yang mengurusi tentang adiwiyata dilakukan untuk menggali permasalahan guru-guru dalam mempersiapkan dan merancang program adiwiyata. berdasarkan wawancara diperoleh hasil bahwa merancang program adiwiyata diawali dengan pembentukan tim, memperhatikan 4 (empat) komponen penilaian adiwiyata, mengubah kebijakan sekolah menuju sekolah berbudaya lingkungan, kemudian merancang program pembelajaran yang diintegrasikan dengan kegiatan dan sarana prasarana sekolah. Pihak DLH merekomendasikan agar tim PKM melakukan suatu kegiatan yang dapat membantu sekolah dalam merancang pembelajaran. Berdasarkan observasi terhadap dokumen RPP sekolah yang mengajukan adiwiyata baik tingkat kota maupun tingkat provinsi, didapati bahwa RPP yang ada belum sesuai dengan RPP standar sekolah adiwiyata. Dengan demikian tim PKM sepakat untuk melakukan pelatihan guna meningkatkan kemampuan guru dalam menyusun RPP terintegrasi adiwiyata.

Hasil yang telah dicapai adalah terselenggaranya kegiatan pengabdian kepada masyarakat berupa pelatihan atau workshop dengan tema "Penyusunan RPP Terintegrasi Adiwiyata Berbasis Kearifan Lokal Kepri untuk Guru Calon Sekolah Adiwiyata di Kota Tanjungpinang". Acara dilaksanakan di Aula SDN 013 Tanjungpinang Barat pada Hari Rabu, 10 Oktober 2018. Susunan acara yaitu pembukaaan oleh MC dilanjutkan sambutan oleh ketua pelaksana dan Sekretaris DLH Kota Tanjungpinang (Bapak Hantoni, serta dibuka secara resmi oleh Kepala Dinas Pendidikan Kota Tanjungpinang (Bapak Drs. Huzaifa Dadang AG, M.Si.). Sebelum materi disampaikan, peserta diminta mengisi lembar pretes untuk mengetahui pengetahuan dan pengalaman awal peserta sebelum mengikuti pelatihan, serta diminta mengumpulkan RPP yang telah dimiliki oleh guru baik yang sudah memuat adiwiyata ataupun yang belum.

Pemaparan materi dilaksanakan dalam 2 (dua) sesi yaitu pertama tentang adiwiyata oleh narasumber dari DLH dan materi kedua tentang penyusunan RPP Terintegrasi Adiwiyata Oleh narasumber dari UMRAH. Pada materi kedua diberikan contoh RPP terintegrasi adiwiyata mata pelajaran SMP materi kelistrikan. Setelah pemaparan materi, dilakukan tanya jawab untuk menampung pertanyaan dari peserta. Dari pemaparan kedua materi tersebut, didapatkan 6 pertanyaan. Hal tersebut menunjukkan antusiasme peserta dalam pelatihan. Pertanyaan-pertanyaan tersebut antara lain: RPP boleh digabung untuk berapa pembelajaran?, bagaimana RPP yang pada pembelajaran I ada isu lingkungan sedangkan pada pembelajaran II tidak memuai isu lingkungan?, dokumen 3 dan 4 apakah harus berhubungan dengan isu kritis lokal?, bolehkan ada 2 isu kritis lokal?, dan bagaimana dengan pemilihan isu lokal temulawak?.

Selanjutnya peserta dilatih untuk menentukan isu-isu kritis lokal Kepri sebagai bekal dalam penyusunan RPP. Penyusunan RPP terintegrasi adiwiyata harus melibatkan seluruh guru mata pelajaran, padahal yang diundang hanya 2 orang guru sebagai perwakilan tiap sekolah. Oleh sebab itu, peserta diwajibkan menyusun RPP terintegrasi adiwiyata di sekolah masing-masing dengan pendampingan dari tim pengabdian. Dua minggu kemudian RPP yang telah selesai disusun dikumpulkan ke panitia. Postes diberikan kepada peserta untuk mengetahui pengetahuan dan pengalaman peserta setelah mengikuti pelatihan penyusunan RPP. Dari acara pelatihan ini peserta mendapatkan sertifikat dengan total Jam Pelatihan 32 jam.

Pengembangan materi pelatihan dilakukan dengan wawancara terhadap ahli pendidikan lingkungan dari Kementerian Pendidikan dan Kebudayaan. Beberapa pengetahuan baru didapatkan berdasarkan wawancara tersebut adalah tidak ada kurikulum khusus "adiwiyata". kurikulum yang digunakan oleh sekolah yang menerapkan program adiwiyata adalah kurikulum resmi sesuai regulasi 
Kemendikbud. Hal tersebut dikarenakan "lingkungan" sudah terlingkupi dalam Sistem Pendidikan Nasional (Sisdiknas), Standar Nasional Pendidikan (SNP), dan prinsip KTSP. Dengan demikian ketika kurikulum sekolah sudah mengimplementasikan kurikulum sesuai regulasi Kemendikbud, maka sekolah sudah melakukan pendidikan lingkungan. Sekolah harus mengenali, memahami, dan menganalisis terlebih dahulu regulasi pendidikan nasional agar paham bahwa kepedulian, pengelolaan, pelestarian lingkungan dan pencegahan kerusakan lingkungan merupakan bagian dari tujuan pendidikan dan penumbuhan budi pekerti karakter bangsa Indonesia.

Regulasi pendidikan nasional yang dimaksud antara lain ada pada Standar Isi Permendiknas No.22 Tahun 2006 yaitu "kesadaran dan wawasan termasuk wawasan kebangsaan, jiwa dan patriotisme bela negara, penghargaan terhadap hak-hak asasi manusia, kemajemukan bangsa, pelestarian lingkungan hidup, kesetaran gender, demokrasi, tanggung jawab sosial, kesetaraan pada hukum, ketaatan membayar pajak, dan sikap serta perilaku anti korupsi, dan nepotisme.

Sejalan dengan kesamaan kurikulum yang digunakan oleh sekolah adiwiyata dan sekolah pada umumnya, maka RPP yang digunakan oleh sekolah adiwiyata juga sama dengan RPP yang digunakan oleh sekolah pada umumnya. Yaitu RPP yang dituntut oleh Permendiknas Nomor 22 Tahun 2016 tentang standar proses untuk Satuan Pendidikan Dasar dan Menengah. Prinsip-prinsip penyusunan RPP sering diabaikan oleh pendidik, padahal dalam prinsip-prinsip tersebut memuat juga prinsip-prinsip pembelajaran yang melestarikan lingkungan. Prinsip-prinsip yang dimaksud diberikan tanda dengan huruf tebal (dibold) yaitu sebagai berikut:

a. Perbedaan individual peserta didik antara lain kemampuan awal, tingkat intelektual, bakat, potensi, minat, motivasi belajar, kemampuan sosial, emosi, gaya belajar, kebutuhan khusus,kecepatan belajar, latar belakang budaya, norma, nilai, dan/atau lingkungan peserta didik.

b. Partisipasi aktif peserta didik.

c. Berpusat pada peserta didik untuk mendorong semangat belajar,motivasi, minat, kreativitas, inisiatif, inspirasi, inovasi dan kemandirian.

d. Pengembangan budaya membaca dan menulis yang dirancang untuk mengembangkan kegemaran membaca, pemahaman beragam bacaan, dan berekspresi dalam berbagai bentuk tulisan.

e. Pemberian umpan balik dan tindak lanjut RPP memuat rancangan program pemberian umpan balik positif, penguatan, pengayaan, dan remedi.

f. Penekanan pada keterkaitan dan keterpaduan antara KD, materi pembelajaran, kegiatan pembelajaran, indikator pencapaian kompetensi, penilaian, dan sumber belajar dalam satu keutuhan pengalaman belajar.

g. Mengakomodasi pembelajaran tematik-terpadu, keterpaduan lintas mata pelajaran, lintas aspek belajar, dan keragaman budaya

h. Penerapan teknologi informasi dan komunikasisecara terintegrasi, sistematis, dan efektif sesuai dengan situasi dan kondisi.

Berdasarkan prinsip-prinsip tersebut maka langkah-langkah dalam mengembangkan RPP (adiwiyata) adalah

1. memetakan isu-isu kritis lokal dan global yang harus dilakukan oleh seluruh guru mata pelajaran di sekolah. Identifikasi kondisi lingkungan hidup sekolah/madrasah meliputi potensi dan permasalahan lingkungan hidup sekolah/madrasah berdasarkan potensi dan permasalahan lingkungan hidup daerah. Aspek yang dikaji meliputi keanekaragaman hayati, makanan sehat, pengelolaan sampah dan limbah, perubahan iklim, energi, dan air. Instrumen untuk memetakan isu-isu kritis lokal dapat menggunakan analisis SWOT atau instrumen lain yang ada.

Kajian sebaiknya dilaksanakan atau dikembangkan saat pemetaan EDS yang merupakan bagian dari Siklus Sistem Penjaminan Mutu di Sekolah. Contoh pemetaan isu-isu kritis global antara lain: keanekaragaman hayati, pengelolaan sampah dan limbah, perubahan iklim, energi dan air, emisi dan pemanasan global, penipisan lapisan ozon, pencemaran laut oleh plastik, tumpahan minyak, dan bahan beracun dan berbahaya. Contoh pemetaan isu-isu kritis lokal antara lain: pengelolaan sampah dan limbah, energi (keterbatasan air, listrik, lahan, dan lain-lain), terumbu karang, kebakaran hutan, biodiversitas, penambangan liar, kearifan budaya lokal, sungai.

2. menganalisis KD-KD (Kompetensi Dasar) tiap mata pelajaran dengan cara mempersiapkan dokumen KD-KD. Sebaiknya setiap kelas dan setiap mata pelajaran dianalisis KD-KD, dalam artian melaksanakan adiwiyata, agar: semakin banyak siswa yang diajarkan PPLH, menambah skor nilai komponen-komponen adiwiyata, dan pembelajaran semakin beragam.

3. menganalisis keterkaitan KD-KD seluruh mata pelajaran sebagaimana tercantum dalam prinsip penyusunan RPP.

4. memperhatikan Taksonomi Bloom untuk membangun tingkat berpikir siswa 
5. merencanakan skenario bersama. Skenario pembelajaran direncanakan secara bersama oleh guru-guru mata pelajaran agar pembelajaran yang satu dengan yang lain saling terkait.

6. Menyusun RPP dimulai dari menuliskan SK//KI, KD, sampai dengan indikator.

7. Mengembangkan indikator menggunakan rumus $5 \mathrm{~W} 1 \mathrm{H}$ (What, When, Where, Why, Who, How) agar indikator hingga ke tahapan How. Artinya indikator tersebut dpat mengembangkan kemampuan berpikir dari rendah sampai dengan tinggi (LOTS $\rightarrow$ HOTS). Selanjutnya memperhatikan taksonomi bloom.

8. Mengembangkan tujuan pembelajaran dengan cara memperhatikan SKL yang diatur dalam Permendikbud Nomor 20 Tahun 2016 tentang standar kompetensi lulusan pendidikan dasar dan menengah.

9. Menentukan materi. Menentukan semua materi/bahan yang ingin diajarkan yang punya keterkaitan lintas mata pelajaran. Kemudian memperhatikan lampiran standar isi pada Permendikbud Nomor 21 Tahun 2016 tentang standar isis pendidikan dasar dan menengah sesuai tingkat satuan pendidikan.

10. Menyusun langkah-langkah pembelajaran. kegiatan dimulai dengan motivasi dengan cara memberikan bahan pengamatan seperti gamba, data, kliping, cerita, atau bermain peran, untuk menjembatani materi dan tujuan. Selain itu juga menyusun kegiatan dengan memperhatikan rumus 5W1H agar pembelajaran dapat mengembangkan: HOTS (menganalisis, mengevaluasi, dan mencipta), 4C (critical, creative, comunicative, collaborative), dan saintifik (5M:mengamati, menanya, mencoba, menalar, dan mengkomunikasikan).

11. Menentukan berbagai sumber belajar. Sumber belajar dapat dari: buku paket, lingkungan sekitar (kontekstual), data dari kehidupan, buku referensi, ahli (untuk metode wawancara, film/slide/situs dan berita terkait), dan lain-lain.

12. Mengembangkan penilaian. Instrumen penilaian dikembangkan dengan berlandaskan KI 1-4 sehingga menilai ranah kognitif, afektif, dan psikomotor.

Berdasarkan Pretes dan Postes, diketahui bahwa secara umum pengetahuan dan pengalaman peserta dalam penyusunan RPP terintegrasi adiwiyata mengalami peningkatan. Pengetahuan peserta meningkat dari skor angket diawal 61 menjadi 91. Peningkatan pengetahuan tersebut diuraikan dalam Tabel di bawah ini:

Tabel 1. Peningkatan Pengetahuan Peserta Berdasarkan Pretes dan Postes

\begin{tabular}{llll}
\hline No. Soal & Indikator & Skor Awal & Skor Akhir \\
\hline 1 & Seluruh guru (lintas mata pelajaran) harus menyusun RPP & 70 & 94 \\
2 & Indikator pada RPP tidak harus ada kata "lingkungan" & 60 & 90 \\
3 & Landasan hukum penyusunan RPP adalah Permendikbud & 70 & 94 \\
& Nomor 22 Tahun 2016 tentang Standar Proses Pendidikan & & \\
& Dasar dan Menengah & 54 & 90 \\
4 & Yang perlu disiapkan sebelum menyusun RPP & 50 & 87 \\
5 & Prinsip-prinsip penyusunan RPP & 61 & 91 \\
Total & & \\
\hline
\end{tabular}

Pengetahuan awal peserta menunjukkan bahwa masih ada anggapan, yang harus menyusun RPP adiwiyata adalah guru mata pelajaran tertentu atau guru yang tergabung dalam tim adiwiyata saja. Anggapan tersebut dapat dimaklumi karena ternyata yang menjawab adalah guru dari sekolah yang belum pernah sama sekali mendapat wawasan tentang adiwiyata. Begitu juga pada indikator kedua, peserta masih ada yang menganggap bahwa indikator pada RPP harus ada kata lingkungan.

Sedangkan landasan hukum penyusunan RPP dijawab oleh 3 orang peserta yaitu UU Nomor 32 Tahun 2009 tentang PPLH, dan 5 peserta menjawab 6 Permen LH Nomor 2 Tahun 2009 tentang Pedoman Pelaksanaan Program Adiwiyata. Hal ini menunjukkan bahwa peserta masih ada yang menganggap bahwa ada kurikulum atau RPP khusus jika melaksanakan adiwiyata. Berdasarkan ketiga indikator yang sudah dibahas atas, dapat diketahui bahwa pengetahuan awal peserta tentang RPP (adiwiyata) ini sudah cukup baik, namun berdasarkan temuan di lapangan menunjukkan bahwa guru masih kesulitan mengimplementasikan pengetahuan tersebut ketika diminta menyusun RPP.

SMPN 10 Tanjungpinang merupakan calon sekolah adiwiyata tingkat nasional. Guru dari SMP yang diundang dalam pelatihan mengaku tercerahkan setelah mengikuti pelatihan ini. Beliau mengatakan bahwa pemetaan isu-isu kritis lokal inilah yang harus dilakukan diawal, sehingga mata pelajaran-mata pelajaran tersebut mempunyai arah yang jelas ketika akan mengembangkan KD-KD. 
Hasil Postes menunjukkan bahwa 83\% peserta telah memahami bahwa yang perlu disiapkan sebelum menyusun RPP adalah peta konsep/peta pemikiran tentang isu-isu kritis lokal, kompetensi lulusan satuan pendidikan, kompetensi dasar semua mata pelajaran, dan rincian tentang proses sikap, pengetahuan, dan keterampilan Taksonomi Bloom. Sedangkan prinsip-prinsip penyusunan RPP adiwiyata sama dengan RPP pada umumnya yaitu mengakomodasi pembelajaran tematik-terpadu, mengakomodasi keterpaduan lintas mata pelajaran, mengakomodasi lintas aspek belajar, mengakomodasi keragaman budaya, mengakomodasi pembelajaran dari berbagai sumber, dan mengakomodasi pengembangan keetrampilan abad ke-21.

Kemampuan peserta dalam penyusunan RPP terintegrasi adiwiyata juga meningkat, dilihat dari RPP sebelum dan setelah pelatihan. RRP sebelum pelatihan belum disusun berdasarkan prinsip-prinsip penyusunan RPP, ditunjukkan dengan sumber belajar kebanyakan dari buku paket dan LKS, keterampilan abad ke-21 belum dikembangkan, dan belum mengakomodasi lintas aspek belajar. Sedangkan pendampingan ke sekolah-sekolah menunjukkan hasil bahwa sebelum pelatihan RPP disusun dengan tidak memperhatikan keterpaduan lintas mata pelajaran. Hal tersebut ditandai dengan tidak adanya pemetaan isu-isu kritis lokal maupun global. Pada saat pelatihan, peserta dibimbing untuk melakukan pemetaan isu-isu lokal dengan hasil sebagai berikut:

Tabel 2. Daftar Tema pada Pemetaan Isu-isu Kritis Lokal Kepri

\begin{tabular}{lll}
\hline No. & Sekolah & Isu Kritis \\
\hline 1 & SDN 003 Tanjungpinang Barat & Daur ulang sampah \\
2 & SDN 010 Tanjungpinang Barat & Sampah \\
3 & SDN 002 Tanjungpinang Timur & Pengelolaan Sampah dan Limbah \\
4 & SDN 001 Tanjungpinang Barat & Sampah \\
5 & SDN 017 Bukit Bestari & Sampah \\
6 & SDN 002 Tanjungpinang Kota & Ketersediaan Air Terbatas \\
7 & SMPN 11 Tanjungpinang & Krisis Air Bersih \\
8 & SDN 010 Tanjungpinang Timur & Biodiversitas Kepri (Sirih) \\
9 & SMPN 6 Tanjungpinang & Ekosistem \\
10 & SDN 013 Tanjungpinang Barat & Pencemaran Limbah dari Ruko \\
11 & SMPIT Al Madinah & Sampah Plastik \\
12 & SMPN 10 Tanjungpinang & Sampah Plastik \\
\hline
\end{tabular}

Berdasarkan Tabel 2 menunjukkan bahwa isu kritis yang paling banyak dinyatakan oleh peserta adalah tentang sampah. Hal tersebut dapat dijadikan perhatian bahwa sampah terutama plastik, masih menjadi masalah utama dalam kehidupan baik di sekolah maupun masyarakat. Sampah plastik harus dikelola dengan baik oleh khususnya sekolah adiwiyata. Lisdiani dkk (2016) menyatakan bahwa pemanfaatan limbah plastik dengan cara pemakaian kembail (reuse) dapat dilakukan dengan berkreasi dan berinovasi menjadi produk handycraft, sedangkan recycle, dilakukan terhadap limbah plastik yang masih memungkinkan disiapkan menjadi biji plastik/dilebur kembali untuk digunakan sebagai produk baru.

RPP setelah pelatihan menunjukkan peningkatan kualitas dengan adanya motivasi dan apresiasi yang kreatif dengan cara memberi bahan pengamatan berupa video, cerita, gambar, dan berita. Selain itu adanya pengembangan indikator yang telah mengakomodasi taksonomi bloom, keterampilan abad ke-21, dan pendekatan saintifik. Kegiatan pembelajaran juga difokuskan pada keberagaman kompetensi siswa. Dapat disimpulkan bahwa kegiatan pengabdian ini dapat meningkatkan kemampuan guru dalam merancang RPP (adiwiyata). Sejalan dengan kegiatan pengabdian Pujani (2018), bahwa pelatihan pembuatan alat peraga ilmu pengetahuan bumi antaraiksa dapat meningkatkan keterampilan guru dalam mengembangkan perangkat pembelajaran dan implementasi perangkat dan alat peraga dalam pembelajaran.

Kegiatan pengabdian ini direkomendasikan karena memiliki keunggulan-keunggulan antara lain: 1) keterlibatan pihak dinas pendidikan dan dinas lingkungan hidup kota dalam metode mengundang peserta dan sambutan acara memberikan dampak yang positif terhadap kehadiran dan keaktifan peserta, 2) pemaparan materi oleh ahli adiwiyata dari DLH dan kampus membuat pengetahuan dan pengalaman guru dalam merancang pembelajaran adiwiyata semakin sempurna, 3) pengembangan materi dilakukan dengan berkonsultasi langsung dengan ahli adiwiyata dari kemdikbud pusat, serta 4) metode pengabdian yaitu dengan memberikan pelatihan dan pendampingan langsung. Kegiatan pengabdian tentang adiwiyata semacam ini, harus ditambah kuantitas dan kualitasnya, agar semua sekolah di Kota Tanjungpinnang 
khususnya mengikuti program adiwiyata. Seperti halnya pengabdian yang dilakukan oleh Tim PKM Universitas PGRI Semarang (2018) tentang pendampingan dan pelatihan untuk sekolah binaan adiwiyata tentang teknik-teknik hidroponik.

\section{Simpulan dan Saran}

Simpulan yang dapat diperoleh dari uraian di atas adalah kegiatan pengabdian kepada masyarakat berupa pelatihan penyusunan RPP terintegrasi adiwiyata berbasis kearifan lokal Kepri bagi guru calon sekolah adiwiyata di Tanjungpinang berlangsung dengan baik dan lancar. Guru-guru dari sekolah yang diundang antusias dan terlibat aktif dalam mengikuti kegiatan. Hasil yang dicapai adalah adanya peningkatan pengetahuan dan keterampilan guru dalam menyusun RPP. Selain itu tim menemukan suatu konsep yang penting kaitannya adiwiyata ini yaitu tidak adanya kurikulum dan RPP khusus adiwiyata, kurikulum dan RPP sekolah yang melaksanakan program adiwiyata sama dengan regulasi kurikulum dari Kementerian Pendidikan Nasional. Selanjutnya, penyusunan RPP diawali dengan pemetaan isu-isu kritis lokal daerah.

Saran yang dapat diberikan adalah sekolah harus lebih kenali dan pahami dengan baik dan tuntas regulasi kurikulum dari Kementerian Pendidikan Nasional. Pelatihan dan pendampingan terkait pelaksanaan adiwiyata harus terus dilakukan agar semua sekolah di Tanjungpinang mengikuti program adiwiyata. Oleh karena itu, pengabdian kepada masyarakat sejenis ini sangat penting didorong dan diberikan peluang yang besar

\section{Daftar Pustaka}

Anwari, A.M.A. 2014. Strategi Pembentukan Karakter Peduli Lingkungan di Sekolah Adiwiyata Mandiri. Jurnal Ta'dib, Vol. XIX, No.02, 227-252.

Desfandi, M. 2015. Mewujudkan Masyarakat Berkarakter Peduli Lingkungan melalui Program Adiwiyata. Social Science Education Journal, 2 (1), 31-37.

Hindrasti, N.E.K. dan Sabekti, A.W. 2017. Profil Kearifan Lokal Kepri (Kepulauan Riau) Berbasis Lingkungan sebagai Pendekatan Pembelajaran Sains. Prosiding SEMIRATA Jambi 2017.

Lisdiana, W., Priyantini, dan Nurrohmah, S. 2016. Pengelolaan Sampah Plastik di Lingkungan Sekolah Adiwiyata. Prosiding Seminar Nasional Unmas Denpasar.

Manurung, Y.L. 2011. Program Adiwiyata dalam Pengelolaan Lingkungan Sekolah (Studi Kasus SDN Panggung 04 Kecamatan Jepara Kabuopaten Jepara Provinsi Jawa Tengah). Tesis. Tidak diterbitkan. Semarang: PPS Universitas Diponegoro.

Mulyana, R. 2009. Penanaman Etika Lingkungan Melalui Sekolah Peduli dan Berbudaya Lingkungan. Jurnal Tabularasa. PPs Unimed Vol. 6 No.2 Desember 2009.

Peraturan Menteri Lingkungan Hidup No.05 Tahun 2013 tentang Pedoman Pelaksanaan Program Adiwiyata.

Peraturan Menteri Pendidikan dan Kebudayaan Nomor 22 Tahun 2016 tentang Standar Proses untuk Satuan Pendidikan Dasar dan Menengah.

Pujani, N.M. 2018. Pelatihan Pembuatan Alat Peraga Ilmu Pengetahuan Bumi Antaraiksa bagi Kelompok Guru SMP dan SMA Lab. Undiksha Singaraja. International Journal of Community Service Learning, 2(1).

R, Rivanna Citraning, Nurwahyunani, A., dan Rosyida. 2018. PKM Sekolah Adiwiyata Se-Kabupaten Demak. Laporan Pengabdian.

Saragih, A.A. 2012. Pengaruh Progrm Adiwiyata terhadap Kognitif, Afektif, dan Psikomotorik Lingkungan hidup Siswa Sekolah Dasar di Kota Medan (Studi Kasus di SD Swasta Pertiwi dan SDN 06 Kecamatan Medan Barat). Tesis. Tidak diterbitkan. Medan: Sekolah Pascasarjana Universitas Sumatera Utara Medan. 
Suratman, B., Surjanti, J., Harti, Sulistyowati, R., dan Wulandari, S.S. 2017. Peningkatan Kreativitas Guru melalui Pelatihan Model Pembelaaran Saintifik Berbasis Pantai dan Laut di Daerah Pesisir Pantai Sidoarjo. Jurnal ABDI, Vol.2 N0.2 hal 1-6.

Undang-undang Nomor 32 Tahun 2009 pasal 65 ayat (2) tentang Perlindungan dan Pengelolaan Lingkungan Hidup.

Zoer’aini, I.D. 2012. Ekosistem Lingkungan dan Pelestariannya. Jakarta: Bumi Aksara. 